\title{
THE IMPORTANCE OF DIFFERENT LEADERSHIP ROLES IN THE STRATEGIC MANAGEMENT PROCESS
}

\author{
MOJAKI S MOSIA \\ THEO H VELDSMAN \\ Leadership in Performance and Change \\ Department of Human Resource Management \\ Rand Afrikaans University
}

\begin{abstract}
The drive towards flatter and more flexible, empowered, interdependent and responsive organisations in the current rapidly changing global situation necessitates the establishment of an integrated set of leadership roles. The purpose of this study was to propose the Integrated Leadership-Champion Framework (IL-C); and to determine empirically the importance of the IL-C for, as well as the importance of the sub-roles of the IL-C across the strategic management processes. The IL-C as a complete leadership framework could enable organisations to execute their strategic management processes more effectively and efficiently. The empirical study demonstrated the importance of IL-C overall and its leadership sub-roles for the strategic management processes.
\end{abstract}

\section{OPSOMMING}

Die soeke na platter, asook meer buigsame, bemagtigde, interafhanklike en responsiewe organisasies in die huidige vinnig veranderende, globale omgewing noodsaak die daarstelling van 'n geintegreerde stel van leierskaprolle. Die doel van hierdie studie was om 'n Geintegreerde Leierskap-kampioen Raamwerk (GL-R) voor te stel; en om empiries die belangrikheid van die GL-R vir, asook die belangrikheid van die subrolle van GL-R oor die strategiese bestuursprosesse te bepaal. Die GL-R as ' $n$ volledige leierskapraamwerk kan organisasies in staat stel om hul strategiese bestuursprosesse meer doeltreffend en doelmatig te bestuur. Die empiriese studie toon die belangrikheid van GL-R oorhoofs, asook sy onderskeie leierskapsubrolle vir die strategiese bestuursprosesse.

\begin{abstract}
Achieving strategic business objectives; positioning the organisation for sustainable growth; and competing in the global arena has placed a new demand on organisations. The challenge is to identify those leadership roles that can make a real difference to organisational performance. The core issue is the leadership role enacted. The successful development of strategy formulation, implementation and evaluation requires a sustained and co-ordinated commitment from top leadership. So does successful strategy change (Chapman, 2002, p. 18; Mattis, 2001, p. 372). Leadership needs to identify new pathways for the organisation to follow, allowing it to build momentum for the future.
\end{abstract}

Chapman (2002, p. 22) adds that strategic change in any organisation impacts on all employees, albeit in different ways at different levels. During the strategising process top leadership strives to fit its strategies into an accurately described environment. Top leadership acknowledges that strategies emerge from the best fit achieved with customers, which highlights the importance of leadership roles at grass root level. Everyone leading a team is managing a small organisation, as all the functions that take place in a large organisation take place in a team (Margerison, 2001, p. 121). For example, the group executive committee of an organisation, led by its chief executive officer, is a small organisation because the team represents the whole organisation.

\section{Leadership in organisations}

Leadership is defined by many researchers as an influencing process that is aimed at directing a group toward the achievement of objectives (Conradie, 2001, p. 36; Robbins, 1998, p. 303). In the process leadership helps and enables followers to remain focused on objectives (Leichtling, 2000, p. 28; Melilli, 2000 , p. 8; Schultz, 2000, p. 94). The effectiveness of leadership in directing and influencing others is seen in improved outputs.

In this study leadership is seen as a dynamic-energetic process which consists of an interconnected and interdependent set of roles to energise a group toward the realisation of goals. A role

Requests for copies should be addressed to: TH Veldsman, Department of Human Resource Management, RAU University, PO Box 524, Auckalnd Park, 2006 in this context is defined as a set of behaviours associated with the leadership process. The leader derives meaning for life out of helping others to realise their goals within the organisational context. The individual's energy then flows naturally into serving other.

For optimum benefits appropriate competencies required for the execution of strategic functions must be identified and developed. Leadership contributions in organisations occur through processes that can be defined as coherent sets of actions performed. The latter statement implies that for each leadership role, there are processes to be performed.

\section{Leadership roles}

A leadership role pertains to "the observable way of performing leadership". The question is, what do those roles look like? According to Graetz (2000, p. 550) and Mattis (2001, p. 375), one of the roles of leadership involves providing strategic direction. Thompson and Strickland (1999, p. 37) and Smit (1999, p. 148) see the challenges of this leadership role as being, firstly, to provide a shared vision of where the organisation is heading and what its purpose is (the mission). The second challenge is to set objectives, that is, to convert the strategic vision and directional course into specific performance outcomes for each key area which leaders deem important for success. The third challenge in providing strategic direction is to generate and develop a strategy that will determine how to achieve the objectives. Strategic direction is imperative in identifying a systematic intervention that will provide the most leverage to the organisation, as an organisation cannot focus on everything all of the time.

The focus of strategy implementation is about positioning and managing organisational and environmental forces during the strategic roll-out in order to ensure operational efficiency. The challenge of strategy implementation is to fulfill the appropriate leadership role of aligning and balancing strategic controls, in terms of both information and behaviour. Imbalanced strategic control systems fail to define the boundaries of acceptable behaviour and lead to inflexibility (Picken \& Dess, 1997, p. 36). 
David (1999, p. 5) and Rodwell, Kienzle and Shadur (1998, p. 278) agree that some strategy implementation problems arise when the structures, culture and rewards of an organisation communicate a different message to what is in the strategic plan. Rewards could be utilised to reinforce and institutionalise the right new behaviour required for strategy implementation (Graetz, 2000, p. 552). The strategic reward plan of the organisation should be made known to all employees (Weizmann, 1999, p. 39). Being an effective communicator therefore appears to be a critical leadership role with respect to strategising.

The inadequate linkage of strategy formulation to implementation could lead to poor execution and results (Koopman, 1999, p. 14). The answer to poor linkage could be found in that leadership role which aligns and integrates all activities of teams in an organisation (Margerison, 2001, p. 120). Leaders playing this role should have the skill to link people and activities for the successful implementation of adopted strategies.

Thompson and Strickland (1999, p. 337) and Koopman (1999, p. $15)$ agree that strategy-culture conflict weakens the successful execution of strategy. They support the idea that culture alignment is needed to make the chosen structures and processes come alive. David (1999, p. 224) supports the latter authors, saying that the structure should be designed to facilitate the strategic pursuit of the organisation, and to ensure that things are done in the right way.

Another leadership role identified by Mattis (2001, p. 377) is that of resourcing. The resources needed must be created, identified and distributed in line with the strategies formulated. An organisation's resource strength is of the utmost importance as resources are the most logical and crucial building blocks for strategy, while their weaknesses may represent vulnerabilities that need corrections (Thompson \& Strickland, 1999, p. 132). Annual objectives serve as guidelines for direction and action, and channel efforts and resources. In allocating resources such as budget and people, leadership needs to know how it can support the strategy to ensure vision realisation (David, 1999, p. 216).

A further leadership role concerns assigning responsibility and accountability (Mattis, 2001, p. 379). Assigning accountability is key to the success of any business venture. People who are empowered and feel accountable are able to implement the strategies developed by top leadership better than those who are not. Establishing accountability by, for example, setting goals and linking them to incentives or rewards could be introduced to inspire the right behaviour (Graetz, 2000, p. $550)$. Everyone in an organisation would like to know what $\mathrm{s} / \mathrm{he}$ is accountable for with respect to strategy formulation, implementation and evaluation.

In strategy evaluation, leadership examines the bases for strategy as well as compares the expected results versus actual results, and develops corrective action plans if there are any deviations. Leadership of the organisation needs to effectively communicate how individual's performance will be measured and what is to be measured (Van Zwieten, 1999, p. 49).

\section{Problem statement}

If leadership consists of a number of roles, and leadership makes a central contribution to the strategic management processes, can these different roles be integrated into a single framework and the importance of the framework with its respective leadership subroles be demonstrated for the strategic management processes?

\section{General research objectives}

The primary objective of the research was to propose an Integrated Leadership-Champion Framework and determine the relative importance of the Integrated Leadership-Champion Framework with its suggested sub-roles for each key process within the strategic management process. The secondary objective was to demonstrate the importance of the Framework with its subroles empirically.

\section{A proposed integrated leadership-champion framework}

The Integrated Leadership Champion Framework (IL-C) was developed relative to the strategic management process.

\section{IL-C Leadership Subroles}

The IL-C consists of five leadership sub-roles namely; StrategicC, Valued-S, Powered-T, Resourceful and Flexible-C Champions. The five IL-C sub roles are discussed in turn.

The Strategic-Change Champion is primarily responsible for setting strategic direction and strategic stewardship. The process of setting strategic direction incorporates strategic thought and action, beginning with the initiation and championing the strategic formulation process, then extend through a systems view to strategic management. Strategic stewardship is about the capacity to implement plans developed during the process of setting the strategic direction to maximise stakeholders' wealth/value.

Strategic-C Champion enjoys generating new ways of looking at things. Strategic-C champions are forward thinkers, foresight, conceptualising and future oriented, and enjoy medium-term and long-term thinking. They are very optimistic about the future despite lack of evidence to other team members. They are the organisation's cheerleaders because of their natural longterm optimism. They are very independent and experimental.

The Valued-Servant Champion connects all the strategic management processes by establishing and championing the shared values and promotes business ethics. Valued-S champion is the Integrated Leadership-Champion sub-role that mobilises, inspires and energises people through adherence to shared values. The Valued-S champion builds trusting relationships which encourage collaboration. The Valued-S champion displays a genuineness to serve.

Valued-S Champions are personal, caring, empathetic and highly interactive with members of their immediate organisation. They harness their ability to engage employees emotionally as well as rationally, harnessing their feelings and nurturing a contagion of energy across the entire organisation. They are the soul caretaker, and likeable and form strong bonds with others. In summary, the Valued-S Champions are: humble, sensitive, value, principle and ethical oriented, listen attentively and willing to serve and are very respectful.

The Powered-Team Champion is an Integrated LeadershipChampion sub-role primarily accountable for establishing and managing cascaded goal and team management. The Powered-T champion identifies team member's readiness to take on certain responsibilities and then distributes his/her powers to those who can accept both responsibility and accountability. These champions link team members and different work processes together to ensure effectiveness and implant self confidence and autonomy in them.

The Powered-T Champion typically displays participation and encouragement. S/he encourages others for independent thinking, aligns team members' personal work preferences with the demands of the job, that is matching the person to the job. The Powered-T Champion gives authority and holds team members accountable for the results of their work and enables team members to solve conflict that arise in cross-functional teams.

The Resourceful Champion adds value through the resource management process, employee development process and organising process. Resourceful Champion is the IL-C sub-role 
that influences organisational processes through the identification of the core resources required for the achievement of set goals. The Resourceful Champion organises, aligns and distributes the available resources according to the strategic needs of the organisation.

Resourceful Champions have a passion to develop people and organise resources for them in order to enable them to produce the required results through the utilisation of the allocated resources. The purpose of this role is to ensure that strategy gets implemented successfully by providing stakeholders with resources. In summary, the Resourceful Champions are development oriented, supportive, organised and have a set of contacts.

The Flexible-Control Champion is the IL-C sub-role which applies and makes decisions according to current and future business results and demands. The Flexible-C Champion monitors a broad range of events inside and outside the organisation. S/he monitors the changes between strategy execution and strategy adjustment and provides reasons thereof. This role primarily brings flexibility in an organisation, controls factors that could impede expected output, and leads a group into periodic assessments of organisational strategies.

The Flexible-C Champions display the following characteristics: being very adaptive in their dealings, quick in adjusting to new ways, open-minded, pressing hard for performance/results, tolerating possible ambiguity and ensuring that departments deliver on set goals.

\section{Strategic management processes and IL-C subroles}

Strategic management can be seen as a continuous dynamic process of formulating, implementing, enabling and evaluating cross-functional decisions. The four processes are sequential in execution, and should always be revisited to ensure alignment with new developments brought about by the formulation process which seem to be the only one revisited often or yearly.

Successful organisations require leaders that will initiate and champion the strategy formulation process. The strategy formulation process involves creating a shared vision, clarifying the organisational mission, and setting strategic objectives and select strategies. The process also requires leadership to distinguish the strengths, weaknesses, opportunities, and threats of the organisation as they relate to individuals, processes, and stakeholders. The Strategic-C Champion and the Flexible-C Champion appeared to be appropriate roles to execute these functions, especially the Strategic-C Champion.

During strategy implementation leadership needs to ensure goal congruency amongst individual, process and organisational goals. This process of ensuring congruency involves linking organisational goals with team and individual goals and performance; communicating the set goals to gain employee commitment; and ensuring the attainment of individual, team and organisational goals. This process of goal attainment involves motivating and coaching teams and employees how to set performance goals. The process also involves eliminating barriers to work goal attainment. The IL-C sub-role of Powered$\mathrm{T}$ Champion is of utmost important in this instance.

During strategy enablement leadership enhances employees' performance and influences their behaviour. Leaders identify incentives/rewards that have value for employees. They also need to consider strategic and operational needs in designing an appropriate organisational structure. Leadership creates and institutionalises the right culture which reinforces the strategy being implemented, and then achieving performance goals with the highest standards of ethics and integrity. Leaders determine which resources can optimise job performance, and effectively deploy them to meet the desired business goals. The Resourceful and Flexible-C Champions are the two IL-C sub-roles needed for these functions.
With regard to strategy evaluation leadership leads groups in periodic assessment of the organisation's strategies. Leadership institutionalises a performance measurement system that links critical dimensions of performance within and between all levels of the organisation. They initiate corrective action when performance is not congruent to goals. They revise strategic thinking methods based on periodic assessment, and use strategic milestones and operational performance to indicate progress in selected strategies. The Flexible-C Champion is the IL-C sub-role critical to fulfil these functions well.

\section{METHOD}

\section{Sample}

The sample was drawn from a South African petrol and chemical organisation operating both locally and internationally. The sample was drawn from all functional groups. The total population at PETRO-CHEM is thirty three thousand employees of which one thousand and sixty constitute the leadership group. The test sample consisted of 265 randomly selected leaders, of whom $4.9 \%$ represents the group executive team which forms the first top leadership level. Six percent of the total number represents the group management team which is the second top leadership level; $18.9 \%$ is from the divisional executive, the third leadership level; and $70.2 \%$ represents the area leaders, which is the fourth leadership level.

The majority (28.2\%) of the respondents were in the $15-21$ years category, with a mean of fifteen years service in the organisation. Inversely $56 \%$ of the respondents are less than four years in their current positions, while $44 \%$ had four or more years. The mean years in current position was 4.2 years. The wide spread of years of service afforded the researcher with the opportunity to receive responses from people who have had a good knowledge and exposure to strategic management processes and leadership roles at PETRO-CHEM. Table 1 provide a summary of the target population and questionnaires received.

TABLE 1

TARgET POPULATION

\begin{tabular}{lcccc}
\hline \multicolumn{1}{c}{ Groups } & Population Sample & $\begin{array}{c}\text { Number of } \\
\text { questionnaires } \\
\text { received }\end{array}$ & $\begin{array}{c}\% \text { of } \\
\text { received } \\
\text { questionnaires }\end{array}$ \\
\hline $\begin{array}{l}\text { Group executive } \\
\text { team }\end{array}$ & 13 & 13 & 13 & 100 \\
$\begin{array}{l}\text { Group management } \\
\text { team }\end{array}$ & 25 & 25 & 16 & 64 \\
$\begin{array}{l}\text { Divisional executive } \\
\text { members }\end{array}$ & 50 & 50 & 50 & 100 \\
Area leaders & 550 & 412 & 186 & 45 \\
Total & 638 & 500 & 265 & 53 \\
\hline
\end{tabular}

Table 1 indicates that a total number of five hundred questionnaires were distributed to the sample group. A total of two hundred and sixty five questionnaires were returned. This number represents $53 \%$ of the sample group which is $25 \%$ of the population. No unusable questionnaires were received because the electronic questionnaire was designed in such a way that if a participant left an item s/he was reminded to complete it, prior to submission.

\section{Procedure}

The questionnaires were mailed electronically to all group members except the group executive members who preferred the hard copies. The completed questionnaires were electronically mailed back while others were hand delivered via the internal mail system to the researcher. 
TABLE 2

FIRST AND SECOND ORDER KMO AND BARTLETT TEST ANALYSIS

\begin{tabular}{|c|c|c|c|c|c|c|c|c|}
\hline \multirow{7}{*}{$\stackrel{\cup}{\leftrightarrows}$} & Strategic Management & No. Items & & tracted Factors & KMO Values & & Bartlett's Significance & Alpha \\
\hline & & Processes & $1^{\text {st Order } 2}$ & $2^{\text {nd Order }}$ & $1^{\text {st Order }}$ & $2^{\text {nd Order }}$ & & \\
\hline & Strategy Formulation & 35 & 6 & 1 & .91 & .91 & $<.001$ & 0.93 \\
\hline & Strategy Implementation & 35 & 10 & 1 & .85 & .85 & $<.001$ & 0.90 \\
\hline & Strategy Enablement & 35 & 8 & 1 & .90 & .90 & $<.001$ & 0.92 \\
\hline & Strategy Control-Review & 35 & 8 & 1 & .91 & .87 & $<.001$ & 0.93 \\
\hline & Strategic Management & 35 & 7 & 1 & .94 & .91 & $<.001$ & 0.95 \\
\hline
\end{tabular}

\section{Measuring instrument}

The researcher developed a questionnaire consisting of 35 items based on the following Integrated Leadership-Champion subroles: Valued-S Champion, Strategic-C Champion, Powered-T Champion, Resourceful Champion, and Flexible-C Champion. Each sub-role was measured by seven items.

The purpose of the questionnaire was to assess the importance of the IL-C and its sub-roles across the four strategic management processes. A five-point importance scale was provided for each item, namely: $1=$ Not at all; 2 = Lesser extent; 3 = Some extent; $4=$ Great extent and $5=$ Very great extent. A five-point scale with 3 representing "Some extent" was chosen to avoid central tendency in responding to items. The questionnaire consists of three sections: an instruction section, a biographical information section and the questionnaire as such (35 items).

\section{Psychometric properties of questionnaire}

Validity

To ensure the highest possible measure of content validity, the questionnaire used in this research was referred to experts and peers for content validation. Different experts were asked to determine whether questions really measure what they were intended to measure. The correlation was also done with the literature to ensure relevancy of the questionnaire. Factor analysis was conducted in order to explore the existence of the theoretical constructs.

Before performing factor analysis, the suitability of the correlation matrix for factor analysis was determined. This was done using three methods namely: (1) Bartlett's test of sphericity, (2) the Kaiser-Meyer-Olkin (KMO) Index, and (3) examination of the number of off-diagonal elements in the antiimage covariance (AIC) matrix > .09.

In order to determine the factor structure of the Integrated Leadership-Champion Questionnaire (IL-C) the 35 items were intercorrelated by means of the anti-image correlation matrix, and subjected to a principal factor analysis. Results from the intercorrelation indicate a very high Measure of Sampling Adequacy. In all correlations a MSA values above .80 were yielded. The intercorrelaion was further confirmed through the KMO and Bartlett tests.

According to table 2 in all the four strategic management processes the KMO test yielded a score above .85 , which indicated the appropriateness of conducting a factor analysis. The Bartlett Test for all the strategic management processes yielded a significant level of less than .001, which also indicated the probability that the correlation matrix had significant correlation amongst at least some of the variables. These results remained consistent when conducting the second order analysis of both the KMO and Bartlett analysis tests. The relationships between the variables as represented by the correlation matrix are presented in table 3 .
TABLE 3

SECOND ORDER ANTI-IMAGE CORRELATION MATRIX FOR STRATEGIC MANAGEMENT

\begin{tabular}{ccc}
\hline Item & Strategic Process & OFF-DIAGONAL VALUES \\
\hline 1 & Strategic management & .928 \\
2 & Strategic management & .920 \\
3 & Strategic management & .887 \\
4 & Strategic management & .873 \\
5 & Strategic management & .927 \\
6 & Strategic management & .950 \\
7 & Strategic management & .928 \\
\hline
\end{tabular}

According to table 3 the off-diagonal correlations are above .86 , which proves the existence of an underlying structure between the variables which could form factors. The diagonal elements in the anti-image correlation matrix are the KMO individual statistics for each variable. The off-diagonal variables were significantly positively correlated with each other. Table 4 provides results of the principal axis factor analysis.

TABLE 4

Results of the Principal Axis Factor analysis

\begin{tabular}{ccccccc}
\hline \multicolumn{3}{l}{ Initial Eigenvalues } & \multicolumn{5}{c}{ Extraction Sums of Squared Loadings } \\
Factor & Total & $\begin{array}{c}\text { \% of } \\
\text { Variance }\end{array}$ & Cumulative \% & Total $\begin{array}{c}\text { \% of } \\
\text { Variance }\end{array}$ & Cumulative \% \\
\hline 1 & 4.38 & 62.58 & 62.58 & 3.99 & 57.01 & 57.01 \\
2 & .74 & 10.50 & 73.08 & - & - & - \\
3 & .59 & 8.38 & 81.46 & - & - & - \\
4 & .39 & 5.60 & 87.06 & - & - & - \\
5 & .35 & 5.05 & 92.11 & - & - & - \\
6 & .34 & 4.87 & 96.97 & - & - & - \\
7 & .21 & 3.03 & 100.00 & - & - & - \\
\hline
\end{tabular}

In order to determine the dimensionality of factors, the eigenvalues were calculated. The first order analysis was done and yielded seven eigenvalues greater than unity, suggesting seven factors. Accordingly the seven factors were extracted and rotated to a simple structure by means of a Direct Oblimin rotation (see table 5). The second order rotated matrix yielded one properly determined factor, with high loadings on items 4 , $3,1,5,2,6$, and 7 within the strategic management process. A one factor solution was found in all four of the strategic 
management processes. A one factor solution was postulated which accounted for $62.58 \%$ of the total questionnaire.

TABle 5

Results of THE DiRect ObLimin Rotation FOR STRATEGIC MANAGEMENT

\begin{tabular}{cccc}
\hline Item & Strategic Process & Factor $\mathbf{1}$ & $\mathbf{h}^{2} \mathbf{j}$ \\
\hline 4 & Strategic management & .854 & .730 \\
3 & Strategic management & .836 & .698 \\
1 & Strategic management & .802 .643 & \\
5 & Strategic management & .799 & .639 \\
2 & Strategic management & .787 & .619 \\
6 & Strategic management & .632 & .399 \\
7 & Strategic management & .512 & .262 \\
\hline
\end{tabular}

Given that the IL-C questionnaire is concerned with the measurement of leadership roles, it is perhaps not surprising that the factor analysis gave a one factor solution. However, it is important to highlight that when the content of each of the IL-C sub-roles questionnaire items were investigated, the five constructs entitled "the IL-C sub-roles" appeared to have high face and content validity. The grouping of items for each of these constructs seemed to tap an appropriate range and depth of information which properly relates to the theoretical construct for each IL-C sub-roles. For instance, when the items for the Valued-S Champion are examined in relation to Powered-T Champion each appeared to be measuring different content domains.

Despite the absence of statistical support for the five IL-C sub-roles because of the strong relationships between the constructs, the ILC sub-roles constructs themselves and their associated domains do appear to have convergent and discriminent validity. This indicates the need for further field research in a full convergent and discriminent validity analysis for the five IL-C sub-roles.

\section{Reliability}

In this study item correlation for the five IL-C sub-roles was performed using the Pearson correlation method. The five IL-C subroles items yielded strong positive relationships with significant correlation values of $=0.004$ levels (2-tailed) in all the strategic management processes. In order to determine the contribution each item makes to the whole scale, an item-total correlation was performed. In all the four strategic management processes the Valued-S Champion, Strategic-C Champion and the Powered-T Champion consistently yielded values above the acceptable cut off value of 0.35 . In the strategic management column, a strategic management process, all the IL-C sub role items yielded values above the 0.35 cut off with the exception of item 8 (with a value of .34).

Since the IL-C questionnaire has 35 items rated across the four strategic management columns, it is possible that the low itemtotal correlation values may be an indication of the presence of acquiescence error. A close inspection highlights that in other strategic management columns these items yielded acceptable values. It is therefore suggested that these items be replaced or rephrased in future studies. The second suggestion is to validate the IL-C questionnaire per strategic management process in different sample groups.

In table 6 the Cronbach-coefficient analysis of constructs for this questionnaire is provided. The Integrated Leadership-Champion sub-roles questionnaire yielded in most instances acceptable levels of reliability. The Cronbach Alpha of the different IL-C sub-roles is highly acceptable with the exception of Flexible-C Champion, which proved low at 0.65 and 0.59 for strategy formulation and implementation respectively. However, the average Cronbach Alpha for the Flexible-C Champion is more than acceptable at 0.76 . The other four IL-C sub-roles had Cronbach Alpha's that were above 0.70 and 0.80 in some of the strategic management processes. The overall average Cronbach Alpha is 0.83 , which is high.

TABLE 6

RELIABILITY OF THE INTEGRATED LEADERSHIP-CHAMPION QUESTIONNAIRE

\begin{tabular}{lccccc}
\hline $\begin{array}{l}\text { Integrated } \\
\text { Leadership- } \\
\text { Champion } \\
\text { Constructs }\end{array}$ & $\begin{array}{c}\text { Strategy } \\
\text { Formulation }\end{array}$ & $\begin{array}{c}\text { Strategy } \\
\text { Implementation }\end{array}$ & $\begin{array}{c}\text { Strategy } \\
\text { Enablement }\end{array}$ & $\begin{array}{c}\text { Strategy } \\
\text { Control- } \\
\text { Review }\end{array}$ & $\begin{array}{c}\text { Strategic } \\
\text { Management }\end{array}$ \\
\hline $\begin{array}{l}\text { Valued-S } \\
\text { Champion }\end{array}$ & 0,80 & 0,73 & 0,82 & 0,78 & 0,84 \\
$\begin{array}{l}\text { Strategic-C } \\
\text { Champion }\end{array}$ & 0,76 & 0,71 & 0,77 & 0,82 & 0,84 \\
$\begin{array}{l}\text { Powered-T } \\
\text { Champion }\end{array}$ & 0,82 & 0,70 & 0,76 & 0,78 & 0,83 \\
$\begin{array}{l}\text { Resourceful } \\
\text { Champion }\end{array}$ & 0,85 & 0,77 & 0,76 & 0,83 & 0,87 \\
$\begin{array}{l}\text { Flexible-C } \\
\text { Champion }\end{array}$ & 0,65 & 0,59 & 0,71 & 0,69 & 0,76 \\
$\begin{array}{l}\text { Average Cronbach } \\
\text { Alpha of sub-roles }\end{array}$ & & 0.90 & 0.93 & 0.94 & 0.96 \\
$\begin{array}{l}\text { Integrated } \\
\text { Leadership- } \\
\text { Champion }\end{array}$ & 0.93 & 0.90 & & \\
\hline
\end{tabular}

An inspection of the last row of table 6 shows a high reliability for all of the strategic management processes across the IL-C. The IL-C represents all thirty five items of the questionnaire. The reliability of above 0.91 is outstanding. Thus the researcher concluded that the Integrated Leadership-Champion Questionnaire was reliable.

\section{Statistical analysis}

The Mauchly's Test of Sphericity was used in order to determine whether the differences between means were significant. When the significant level is $=0.05$, it is assumed that the assumption of sphericity has been violated. Knowing that the assumption of sphericity is violated, requires the use of the Huynh-Feldt adjustment method. The Huynh-Feldt Correction adjusts the degrees of freedom in the ANOVA test in order to produce a more accurate significance value.

The ANOVA test was used to test the significant differences across the four strategic management processes. In the case of a significant ANOVA, differences between means were investigated using the Scheffe's test.

In order to determine which IL-C sub-role was linked to which strategic management process, correspondence analysis was used. Correspondence analysis is a descriptive/exploratory technique designed to analyse two-way and multi-way tables containing some measure of correspondence between rows and columns.

\section{Hypotheses}

Two sets of hypotheses were tested, namely (i) null hypotheses relating to the importance of the IL-C across the strategic management process and the impact of the contextual variables on this relationship $\left(\mathrm{Ho}_{1}\right.$ to $\left.\mathrm{Ho}_{5}\right)$; and (ii) null hypotheses relating to the link of the five IL-C sub-roles to the four strategic management processes (Ho6 to Ho10).

\section{RESULTS}

The importance of the IL-C relative to the strategic management process: Testing $\mathrm{Ho} 1$ to $\mathrm{Ho}_{5}$

Table 7 gives a summary of the descriptive statistics regarding the Integrated Leadership-Champion with respect to the four strategic management processes. In strategy implementation and enablement the IL-C is seen to be of greatest importance with a mean of 4.18 and 4.11 respectively. Strategy formulation and control-review received the lowest ratings. 
TABLE 7

DESCRIPTIVE STATISTICS FOR THE IL-C RELATIVE TO THE STRATEGIC MANAGEMENT PROCESSES

\begin{tabular}{|c|c|c|c|c|c|c|c|c|c|c|c|c|}
\hline \multirow{2}{*}{$\begin{array}{l}\text { Strategic management } \\
\text { processes and IL-C }\end{array}$} & \multicolumn{2}{|c|}{$\mathbf{N}$} & \multirow[b]{2}{*}{ Mean } & \multirow[b]{2}{*}{ Median } & \multirow[b]{2}{*}{ Mode } & \multirow[b]{2}{*}{$\begin{array}{c}\text { Std. } \\
\text { Deviation }\end{array}$} & \multirow[b]{2}{*}{ Skewness } & \multirow[b]{2}{*}{$\begin{array}{c}\text { Std. Error } \\
\text { of Skewness }\end{array}$} & \multirow[b]{2}{*}{ Kurtosis } & \multirow[b]{2}{*}{$\begin{array}{l}\text { Std. Error } \\
\text { of Kurtosis }\end{array}$} & \multirow[b]{2}{*}{ Minimum } & \multirow[b]{2}{*}{ Maximum } \\
\hline & Valid & Missing & & & & & & & & & & \\
\hline Strategy Formulation: IL-C & 265 & 0 & 3.77 & 3.82 & 3.60 & .598 & -.731 & .150 & .608 & .298 & 1.71 & 4.97 \\
\hline Strategy Implementation: IL-C & 265 & 0 & 4.18 & 4.22 & 4.54 & .401 & -.986 & .150 & 3.186 & .298 & 1.89 & 5.00 \\
\hline Strategy Enablement: IL-C & 265 & 0 & 4.11 & 4.20 & 4.34 & .487 & -1.242 & .150 & 2.915 & .298 & 1.83 & 4.94 \\
\hline Strategy Control-Review: IL-C & 265 & 0 & 3.78 & 3.85 & 4.03 & .580 & -.689 & .150 & .299 & .298 & 1.83 & 4.94 \\
\hline
\end{tabular}

According to descriptive statistics in table 7 it is clear that the IL-C is of great importance throughout the strategic management processes, even though the degree of importance is different. In strategy implementation and enablement the IL-C is seen to be of greatest important with a mean of 4.18 and 4.11 respectively. Strategy formulation and control-review received the lowest ratings. The expectation could result in a greater need for being empowered and resourced to execute the strategy more effectively.

Throughout the analyses the Mauchly's test was performed (tables not reproduced due to limited space). The null hypotheses of sphericity were rejected, since the significant values were smaller than .001. Accordingly the degrees of freedom for the ANOVA were adjusted. Table 8 gives the ANOVA results for Ho1.

Results and findings regarding $\mathrm{Ho}_{1}$

$\mathrm{Ho}_{1}$ : There is no significant difference between the importance of the Integrated Leadership-Champion across the strategic management processes.

TABLE 8

ANOVA RESULTS FOR THE IMPORTANCE OF THE IL-C BY DIFFERENT LEADERSHIP GROUPS

\begin{tabular}{lccccccc}
\hline Source & $\begin{array}{c}\text { Type III } \\
\text { Sum of } \\
\text { Squares }\end{array}$ & df & $\begin{array}{c}\text { Mean } \\
\text { Square }\end{array}$ & F & $\begin{array}{c}\text { Sig. } \\
\text { Partial Eta } \\
\text { Squared }\end{array}$ \\
\hline IL-C & Huynh-Feldt & 23.797 & 2.674 & 8.899 & 67.756 & .001 & .209 \\
Error(IL-C) Huynh-Feldt & 89.911 & 684.535 & .131 & - & & \\
\hline
\end{tabular}

According to table 8 a significant difference exists across the four sequential strategic management processes in terms of the importance of the Integrated Leadership-Champion. The null hypothesis thus is rejected. In order to find the area(s) where the significant differences lie, the Scheffe's test is applied, the results of which are given in table 9. In table 9 the acronym SF is used to indicate strategy formulation, while SI refers to strategy implementation. SE indicates strategy enablement while SC-R represents the strategy control-review process.

TABLE 9

SCHEFF'S TESTS REGARDING MEAN DIFFERENCE FOR THE STRATEGIC MANAGEMENT PROCESSES

\begin{tabular}{llcccccc}
\hline Source & $\begin{array}{l}\text { Integrated } \\
\text { Leadership- } \\
\text { Champion }\end{array}$ & $\begin{array}{c}\text { Type III } \\
\text { Sum of } \\
\text { Squares }\end{array}$ & df & $\begin{array}{c}\text { Mean } \\
\text { Square }\end{array}$ & F & Sig. & $\begin{array}{c}\text { Partial Eta } \\
\text { Squared }\end{array}$ \\
\hline & SF vs. SI & 31.575 & 1 & 31.575 & 139.189 & .001 & .352 \\
& SF vs. SE & 28.161 & 1 & 28.161 & 85.138 & .001 & .352 \\
IL-C & SF vs. SC-R & 1.280 & 1 & 1.280 & .005 & .945 & .220 \\
& SI vs. SE & 1.504 & 1 & 1.504 & 10.949 & .001 & .041 \\
& SI vs. SC-R & 1.457 & 1 & 1.457 & 10.512 & .001 & .220 \\
& SC-R vs. SE & 15.702 & 1 & 15.702 & 72.134 & .001 & .220 \\
\hline
\end{tabular}

According to table 9 all comparisons yielded significant differences at the 0.01 percent level with the exception of SF vs. SC-R which was non-significant. As indicated previously the strategy implementation mean was higher than those of the other processes.

The strategy formulation process was significantly less important with respect to IL-C when compared to strategy implementation and enablement. Strategy implementation was significantly more important than strategy formulation; enablement; and control-review. Strategy enablement was significantly more important than strategy formulation and control-review. There was no significant difference with respect to strategy formulation and control-review.

Results and findings regarding $\mathrm{HO}_{2}$

$\mathrm{Ho}_{2}$ : There is no significant difference between the perceptions of people with different years of experience in an organisation regarding the importance of the Integrated Leadership-Champion for the key strategic management processes.

TABLE 10

ANOVA RESULTS FOR THE IMPORTANCE OF THE IL-C BY YEARS OF SERVICE IN ORGANISATION

\begin{tabular}{|c|c|c|c|c|c|c|c|}
\hline Source & & $\begin{array}{l}\text { Type III } \\
\text { Sum of } \\
\text { Squares }\end{array}$ & df & $\begin{array}{l}\text { Mean } \\
\text { Square }\end{array}$ & F & Sig. & $\begin{array}{c}\text { Partial } \\
\text { Eta } \\
\text { Squared }\end{array}$ \\
\hline IL-C*YRS IN-ORG. & Huynh-Feldt & 1.248 & 7.976 & .156 & 1.165 & .318 & .013 \\
\hline Error(IL-C) & Huynh-Feldt & 92.108 & 685.928 & .134 & & - & \\
\hline
\end{tabular}

The results in table 10 reveal that there was no significant difference between the perceptions of people with different years of service at PETRO-CHEM in terms of the importance of the IL-C across the strategic management processes. $\mathrm{Ho}_{2}$ is accepted. This result implies that people with different years of service at PETRO-CHEM perceived IL-C as equally important across the various strategic management processes.

Results and findings regarding $\mathrm{Ho}_{3}$

$\mathrm{Ho}_{3}$ : There is no significant difference between the perceptions of people with different years of experience in their current position regarding the importance of the Integrated Leadership-Champion for the key strategic management processes.

Table 11 indicates that there is no significant difference between the perceptions of people with various length of service in their current position regarding the importance of the IL-C with respect to the strategic management processes. Number of years did not influence their perceptions of the IL$\mathrm{C}$ importance regarding the strategic management process. Ho3 is accepted. 
TABLE 11

ANOVA ANALYSIS FOR DETERMINING THE IMPORTANCE OF IL-C BY YEARS IN CURRENT JOB

\begin{tabular}{lccccccc}
\hline Source & & $\begin{array}{c}\text { Type III } \\
\text { Sum of } \\
\text { Squares }\end{array}$ & df & $\begin{array}{c}\text { Mean } \\
\text { Square }\end{array}$ & F & $\begin{array}{c}\text { Sig. } \\
\text { Partial } \\
\text { Eta } \\
\text { Squared }\end{array}$ \\
\hline IL-C * POSITIONS & Huynh-Feldt & .749 & 5.276 & .142 & 1.039 & .395 & .008 \\
Error (IL-C) & Huynh-Feldt & 90.074 & 659.545 & .137 & & - & \\
\hline
\end{tabular}

Results and findings regarding $\mathrm{Ho}_{4}$

$\mathrm{Ho}_{4}$ : There is no significant difference between the perceptions of people at different occupational levels regarding the importance of the Integrated Leadership-Champion for the key strategic management processes.

TABLE 12

ANOVA RESULTS FOR THE IMPORTANCE OF IL-C BY OCCUPATIONAL LEVELS

\begin{tabular}{lccccccc}
\hline Source & & $\begin{array}{c}\text { Type III } \\
\text { Sum of } \\
\text { Squares }\end{array}$ & df & $\begin{array}{c}\text { Mean } \\
\text { Square }\end{array}$ & F & $\begin{array}{c}\text { Sig. } \\
\text { Partial } \\
\text { Eta } \\
\text { Squared }\end{array}$ \\
\hline IL-C * LEVELS & Huynh-Feldt & 1.552 & 5.267 & .295 & 2.185 & .051 & .016 \\
Error(IL-C) & Huynh-Feldt & 93.049 & 689.936 & .135 & & - & \\
\hline
\end{tabular}

According to table 12 a borderline significant value of .051 was found, which the researcher decided to ignore. Different occupational levels thus perceived the IL-C to be equally important across the different strategic management processes. The null hypothesis was accepted. This implies that different occupational levels did not have any significant influence on the perceptions of the four leadership groups at PETRO-CHEM.

Results and findings regarding $\mathrm{Ho}_{5}$

$\mathrm{Ho}_{5}$ : There is no significant difference between the perceptions of people from different core business processes (CBP) regarding the importance of the Integrated LeadershipChampion for the key strategic management processes.

TABLE 13

ANOVA RESULTS FOR DETERMINING THE IMPORTANCE OF IL-C BY CBPS

\begin{tabular}{|c|c|c|c|c|c|c|c|}
\hline Source & & $\begin{array}{l}\text { Type III } \\
\text { Sum of } \\
\text { Squares }\end{array}$ & df & $\begin{array}{l}\text { Mean } \\
\text { Square }\end{array}$ & F & Sig. & $\begin{array}{c}\text { Partial } \\
\text { Eta } \\
\text { Squared }\end{array}$ \\
\hline IL-C * CBP & Huynh-Feldt & 4.373 & 16.044 & .273 & 2.075 & .008 & .046 \\
\hline Error(IL-C) & Huynh-Feldt & 89.911 & 684.535 & 0.131 & & - & \\
\hline
\end{tabular}

According to table 13 the functional groups (CBPs) were significantly different at the .008 level with respect to the importance of the IL-C across the various strategic management processes. Ho5 is therefore rejected. Subsequently the Scheffe's test was performed to determine where the significant differences were. These results are given in table 14

Table 14 indicates a significant difference between the perceptions of different functional groups in terms of the importance of the Integrated Leadership-Champion in strategy enablement vs. strategy control-review.

The plant and mine maintenance group perceived the IL-C to be of great important especially in strategy implementation and enablement while the marketing, liaison and distribution group perceived the IL-C to be equally important in all of the processes. This could be attributed to the differences in the fundamental nature of the two functional groups. The plant and mine maintenance functional group represents a production engineering environment which is production-driven and focuses more on doing while marketing, liaison and distribution group form the marketing and sales team which is more systematic in its approach.

\section{TABLE 14}

SCHEFFE'S TEST FOR DETERMINING SIGNIFICANT DIFFERENCE WITHIN THE CBPS

\begin{tabular}{lccccccc}
\hline Source & & $\begin{array}{c}\text { Type III } \\
\text { Sum of } \\
\text { Squares }\end{array}$ & df & $\begin{array}{c}\text { Mean } \\
\text { Square }\end{array}$ & F & $\begin{array}{c}\text { Sig. } \\
\text { Partial } \\
\text { Eta } \\
\text { Squared }\end{array}$ \\
\hline IL-C * CBP & SF vs. SI & 2.488 & 6 & .415 & 1.828 & .094 & .041 \\
& SI vs. SE & .946 & 6 & .158 & 1.148 & .335 & .026 \\
& SE vs. SC-R & 5.598 & 6 & .933 & 4.286 & .001 & .091 \\
\hline
\end{tabular}

Summary of results with respect to the importance of the $\mathrm{IL}-\mathrm{C}\left(\mathrm{Ho}_{1}\right.$ to $\mathrm{Ho}_{5}$ )

The importance of the Integrated Leadership-Champion in the strategic management processes was investigated and the results of $\mathrm{Ho}_{1}$ to $\mathrm{Ho}_{5}$ could be summarised as follows:

- the importance of IL-C varied significantly across the strategic management processes $\left(\mathrm{Ho}_{1}\right)$. IL-C was significantly more important in the case of strategy implementation and enablement than in relation to strategy formulation and control-review. In turn, strategy implementation is more important than strategy enablement. The overall trend is that the IL-C is more crucial to strategy implementation.

- years of service at PETRO-CHEM $\left(\mathrm{Ho}_{2}\right)$, years in current position $\left(\mathrm{Ho}_{3}\right)$, and occupational level (Ho4), with regard to the importance of the IL-C did not yield any significant differences across the strategic management processes. This implies that the variables of years of service, years in current position and occupational level did not impact significantly on the perceptions of the different leadership groups at PETRO-CHEM with respect to the link between IL-C and strategic management.

- core business processes $\left(\mathrm{Ho}_{5}\right)$ at PETRO-CHEM yielded a significant difference with regard to the importance of the IL$\mathrm{C}$ across the strategic management processes. Amongst all the seven core business processes only one comparison yielded a significant difference, namely the comparison between the plant and mine maintenance group on the one hand and marketing, liaison and distribution group on the other hand. The significant difference occurred at strategy enablement and control-review.

The importance of the IL-C sub-roles relative to the strategic management processes: Testing $\mathrm{Ho}_{6}$ to $\mathrm{Ho}_{10}$

Results and findings regarding $\mathrm{Ho}_{6}$

$\mathrm{Ho}_{6}$ : The Strategic-C Champion will not be ranked as the most critical IL-C sub-role relative to strategy formulation process.

According to table 15 Strategic-C Champion was the most important IL-C sub-role for strategy formulation process (57.9\%); and the most important sub-role overall relative to all of the other sub-roles $(58.8 \%)$. These findings thus prove in two ways a strong link between this sub-role and strategy formulation.

Within the overall strategic management process, the Strategic-C Champion was rated as the most critical sub-role $(24.8 \%)$. Inversely, for the other three strategic management processes the Strategic-C Champion was rated as less important, but never perceived as least important in any of these processes. For the control-review process it was the 2 nd most important IL-C subroles, 3rd for the implementation, and 4th for the enablement process. Ho6 thus needs to be rejected. 
TABLES 15

RESULTS OF THE FOUR LEADERSHIP GROUP AT PETRO-CHEM WITH REgARD TO MOST CRITICAL IL-C SUB-ROLES RELATIVE TO STRATEGIC MANAGEMENT PROCESSES

\begin{tabular}{|c|c|c|c|c|c|c|c|c|c|}
\hline \multicolumn{10}{|c|}{ The Integrated Leadership Champion Sub-Roles } \\
\hline & & Leadership vs. Strate & uctsValued-S & Strategic-C & Powered-T & Resourceful & Flexible-C & Combination & Total \\
\hline \multirow{12}{*}{ 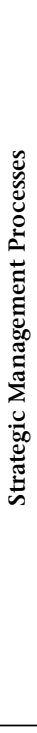 } & \multirow{6}{*}{ 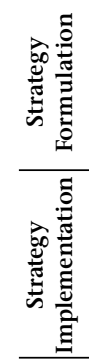 } & Count & 24 & 147 & 11 & 13 & 17 & 42 & 254 \\
\hline & & $\%$ within Strategy & $9.4 \%$ & $57.9 \%$ & $4.3 \%$ & $5.1 \%$ & $6.7 \%$ & $16.5 \%$ & $100.0 \%$ \\
\hline & & \% within IL-C Role & $14.3 \%$ & $58.8 \%$ & $8.0 \%$ & $7.4 \%$ & $21.8 \%$ & $21.1 \%$ & $25.2 \%$ \\
\hline & & Count & 21 & 36 & 56 & 84 & 6 & 48 & 251 \\
\hline & & $\%$ within Strategy & $8.4 \%$ & $14.3 \%$ & $22.3 \%$ & $33.5 \%$ & $2.4 \%$ & $19.1 \%$ & $100.0 \%$ \\
\hline & & \% within IL-C Role & $12.5 \%$ & $14.4 \%$ & $40.6 \%$ & $48.0 \%$ & $7.7 \%$ & $24.1 \%$ & $24.9 \%$ \\
\hline & \multirow{3}{*}{ 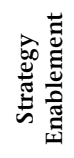 } & Count & 71 & 24 & 41 & 39 & 13 & 65 & 253 \\
\hline & & \% within Strategy & $28.1 \%$ & $9.5 \%$ & $16.2 \%$ & $15.4 \%$ & $5.1 \%$ & $25.7 \%$ & $100.0 \%$ \\
\hline & & \% within IL-C Role & $42.3 \%$ & $9.6 \%$ & $29.7 \%$ & $22.3 \%$ & $16.7 \%$ & $32.7 \%$ & $25.1 \%$ \\
\hline & \multirow{3}{*}{ 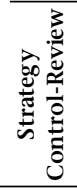 } & Count & 52 & 43 & 30 & 39 & 42 & 44 & 250 \\
\hline & & \% within Strategy & $20.8 \%$ & $17.2 \%$ & $12.0 \%$ & $15.6 \%$ & $16.8 \%$ & $17.6 \%$ & $100.0 \%$ \\
\hline & & \% within IL-C Role & $31.0 \%$ & $17.2 \%$ & $21.7 \%$ & $22.3 \%$ & $53.8 \%$ & $22.1 \%$ & $24.8 \%$ \\
\hline \multirow{3}{*}{\multicolumn{2}{|c|}{ Total }} & Count & 168 & 250 & 138 & 175 & 78 & 199 & 1008 \\
\hline & & $\%$ within Strategy & $16.7 \%$ & $24.8 \%$ & $13.7 \%$ & $17.4 \%$ & $7.7 \%$ & $19.7 \%$ & $100.0 \%$ \\
\hline & & \% within IL-C Role & $100.0 \%$ & $100.0 \%$ & $100.0 \%$ & $100.0 \%$ & $100.0 \%$ & $100.0 \%$ & $100.0 \%$ \\
\hline
\end{tabular}

Results and findings regarding $\mathrm{Ho}_{7}$

$\mathrm{Ho}_{7}$ : The Resourceful Champion will not be ranked as the most critical IL-C sub-role relative to the strategy implementation process.

According to table 15 the Resourceful Champion was rated the most critical IL-C sub-role relative to strategy implementation (33.5\%). The importance of the Resourceful Champion for strategy implementation is also supported by its highest rating within the IL-C sub-roles (48.0\%). The findings therefore prove in two ways a strong link between Resourceful Champion and strategy implementation.

Across the strategic management process the Resourceful Champion was perceived to be the second most critical IL-C subroles (17.4\%). Regarding the other three processes, the Resourceful Champion was 3rd in importance regarding strategy enablement and control-review. With respect to strategy formulation it was the least important IL-C sub-role. $\mathrm{Ho}_{7}$ is therefore rejected.

Results and findings regarding $\mathrm{Ho}_{8}$

$\mathrm{Ho}_{8}$ : The Powered-T Champion will not be ranked as the most critical IL-C sub-role relative to the strategy implementation and enablement processes.

According to table 15 the Powered-T Champion was the second most important IL-C sub-role for the strategy implementation process $(22.3 \%)$. The Powered-T Champion was the second important sub-role for this process relative to all of the other sub-roles $(40.6 \%)$.

Within the strategic management process the Powered-T Champion was perceived as the second least IL-C sub-role (13.7\%). Despite being the second important IL-C sub-role within strategy implementation, it is concluded that the best place for this sub-role is in implementation. Powered-T Champion was perceived as more important in strategy enablement than in implementation when compared to all other IL-C sub-roles. $\mathrm{Ho}_{8}$ is therefore rejected.

Results and findings regarding $\mathrm{Ho}_{9}$

$\mathrm{Ho}_{9}$ : The Flexible-C Champion will not be ranked as the most critical IL-C sub-role relative to the strategy control-review process.

According to table 15 the Flexible-C Champion was the third most critical IL-C sub-role with respect to the strategy controlreview process $(16.8 \%)$. Within the IL-C the Flexible-C Champion was perceived as the most critical IL-C sub-role regarding strategy control-review (53.8\%). This finding indicated a weaker relationship since Flexible-C Champion's importance was only confirmed in one instance.

Across the strategic management process the Flexible-C Champion was perceived as the least important IL-C sub-role (7.7\%). The Flexible-C Champion's visibility is in the strategy control-review process. Ho9 is therefore accepted.

Results and findings regarding $\mathrm{Ho}_{10}$

$\mathrm{Ho}_{10}$ : The Valued-S Champion will not be ranked as the most critical IL-C sub-role relative to key strategic management processes.

According to table 15 the Valued-S Champion was the most critical IL-C sub-role relative to strategy enablement (28.1\%) and to the strategy control-review (20.8\%). Valued-S Champion was perceived as a key sub-role in the enablement process (42.3\%), and second most important regarding control-review, when compared with the other IL-C sub-roles.

With respect to strategy formulation and implementation the Valued-S Champion was rated the second and third most important IL-C sub-role respectively. These results yielded a weak link since the Valued-S Champion was expected to show a strong link to all of the four strategic management processes. 
Within the strategic management process the Valued-S Champion was the third most important IL-C sub-role (16.7\%). $\mathrm{Ho}_{10}$ is therefore accepted.

\section{Correspondence analysis}

As mentioned earlier, correspondence analysis is a descriptive/ exploratory technique designed to analyse two-way and multiway tables containing some measure of correspondence between rows and columns. The bi-plot is a diagram which simultaneously plots species scores and sample scores within the correspondence analysis.

Table 16 indicates that the chi-square value is significant, justifying the hypothesis that the IL-C sub-roles and strategic management processes are related. Interpoint distances were computed. The distance matrix was subjected to principal components analysis, yielding in this case three dimensions. However, only two interpretable dimensions are reported, and not the full solution, which is why the inertia (eigenvalues; these represent the percent of variance explained by each dimension) adds up to less than hundred percent, in this case only $.328=$ $32.8 \%$. This reflects the fact that the correlation between the IL$\mathrm{C}$ sub-roles and strategic management processes is not very strong. The inertia "eigenvalues" reflect the relative importance of each dimension, with the first always being the most important and the second one being the next most important.

The "Proportion of Inertia" columns represent the dimension eigenvalues divided by the total (table) eigenvalue. The first dimension explains $67.4 \%$ variance of the $32.8 \%$ of the total variance explained by the model, while the second dimension explains $24 \%$. Sixty seven point four percent of data in the biplot is represented by the first dimension, while $24 \%$ is represented by the second dimension. Only $8.6 \%$ of data is not represented in the bi-plot. Figure 1 provides a bi-plot of the IL-C sub-roles. In the bi-plot the $\mathrm{x}$-axis (dimension 1 ) represents the strategic management processes while the y-axis (dimension 2) represents the Integrated Leadership-Champion sub-roles.

On close inspection of the bi-plot given in figure 1 it is evident that information is clustered. The information clustered consists of the strategic processes and the IL-C subroles. It is shown that some strategic management processes are clustered or associated with some IL-C sub-roles. The first observable cluster is the one of the Strategic-C Champion and the strategy formulation process. This cluster supports the $\mathrm{Ho}_{1}$ rejected earlier.

The second perceptible cluster is that of the Powered-T Champion, Resourceful Champion and the strategy implementation process. An inference from the above combination is that the Powered-T Champion and Resourceful Champion are the IL-C sub-roles linked or regarded as most critical in the strategy implementation. Table 15 indicates that the Powered-T Champion was the second most critical IL-C subrole relative to the strategy implementation process. This finding supports the results reported in table 15 regarding $\mathrm{Ho}_{2}$ and $\mathrm{Ho}_{3}$.

The third noticeable cluster is that of the Valued-S Champion, Flexible-C Champion and strategy control-review. This upperleft quadrant cluster strongly supports the results given in table 15 indicating that the Valued-S Champion is the most critical IL-C Champion relative to the strategic controlreview process $\left(\mathrm{Ho}_{4}\right)$, with the Flexible-C Champion being second $\left(\mathrm{Ho}_{5}\right)$.

Summary of results with respect to the importance of the $I L-C$ subroles $\left(\mathrm{Ho}_{6}\right.$ to $\left.\mathrm{Ho}_{10}\right)$

Findings of $\mathrm{Ho} 6$ to $\mathrm{Ho}_{10}$ regarding the most important IL-C subrole relative to specific strategic management processes can be summarised as follows:

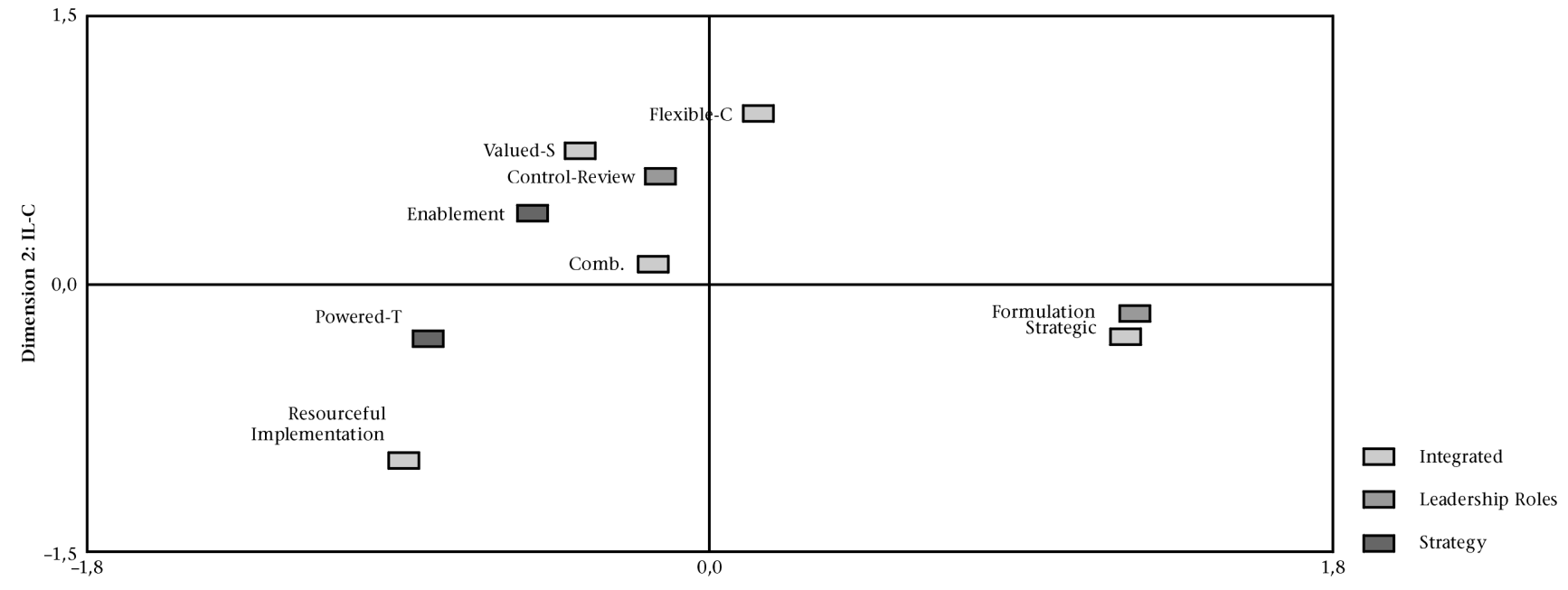

Dimension 1: Strategic Management Processes

Figure 1: Bi-plot of the IL-C sub-roles and strategic management processes

TABLE 16

STATISTICAL SUMMARY OF THE BI-PLOT

\begin{tabular}{|c|c|c|c|c|c|c|c|}
\hline \multirow[t]{2}{*}{ Dimension } & \multirow[t]{2}{*}{ Singular Value } & \multirow[t]{2}{*}{ Inertia } & \multirow[t]{2}{*}{ Chi Square } & \multicolumn{2}{|c|}{ Sig. Proportion of Inertia } & \multicolumn{2}{|c|}{ Confidence Singular Value } \\
\hline & & & & Accounted for & Cumulative & $\begin{array}{c}\text { Standard } \\
\text { Deviation }\end{array}$ & $\begin{array}{c}\text { Correlation } \\
2\end{array}$ \\
\hline 1 & .470 & .221 & & .674 & .674 & .029 & .124 \\
\hline 2 & .280 & .079 & & .240 & .914 & .029 & \\
\hline 3 & .167 & .028 & & .086 & 1.000 & & \\
\hline Total & & .328 & 330.293 & .000 & 1.000 & & \\
\hline
\end{tabular}


- The Strategic-C Champion was the most important IL-C subrole for strategy formulation process, as well as the most important sub-role relative to all of the other sub-roles and across the overall strategic management process $\left(\mathrm{Ho}_{6}\right.$ : Rejected).

- The Resourceful Champion was the most important IL-C subrole for strategy implementation, and also first to this process when compared to other IL-C sub-roles. Across the strategic management process it was $2^{\text {nd }}$ in importance $\left(\mathrm{Ho}_{7}\right.$ : Rejected).

- The Powered-T Champion was the second most important IL$\mathrm{C}$ sub-role relative to strategy implementation and enablement. It was $2^{\text {nd }}$ when compared to the other IL-C subroles within the IL-C. Across the strategic management processes it was $4^{\text {th }}$ in importance $\left(\mathrm{Ho}_{8}\right.$ : Accepted).

- The Flexible-C Champion was the third most important IL-C sub-role for strategy control-review; and most important subrole to this process relative to all other sub-roles. The Flexible-C Champion was the $2^{\text {nd }}$ most important IL-C subrole for strategy formulation, but the $4^{\text {th }}$ important IL-C subrole across the strategic management process ( $\mathrm{Ho}_{9}$ : Accepted).

- The Valued-S Champion had a strong link to strategy enablement and control-review, with weaker links with both strategy formulation and implementation. The Valued-S Champion was the most important IL-C sub-role for strategy enablement and control-review; third for formulation; and fourth for implementation, when compared to the other IL-C sub-roles. Across the strategic management process the Valued-S Champion was the third most important IL-C sub-role $\left(\mathrm{Ho}_{10}\right.$ : Accepted).

\section{DISCUSSION AND INTERPRETATION}

As discussed earlier the following three proposals pertaining to the IL-C and the strategic management processes were made, namely; (i) the IL-C is important across the four strategic management processes, (ii) specific IL-C sub-roles relate closer to specific strategic management processes, and (iii) contextual variables do not impact on the importance of the IL-C across the strategic management process.

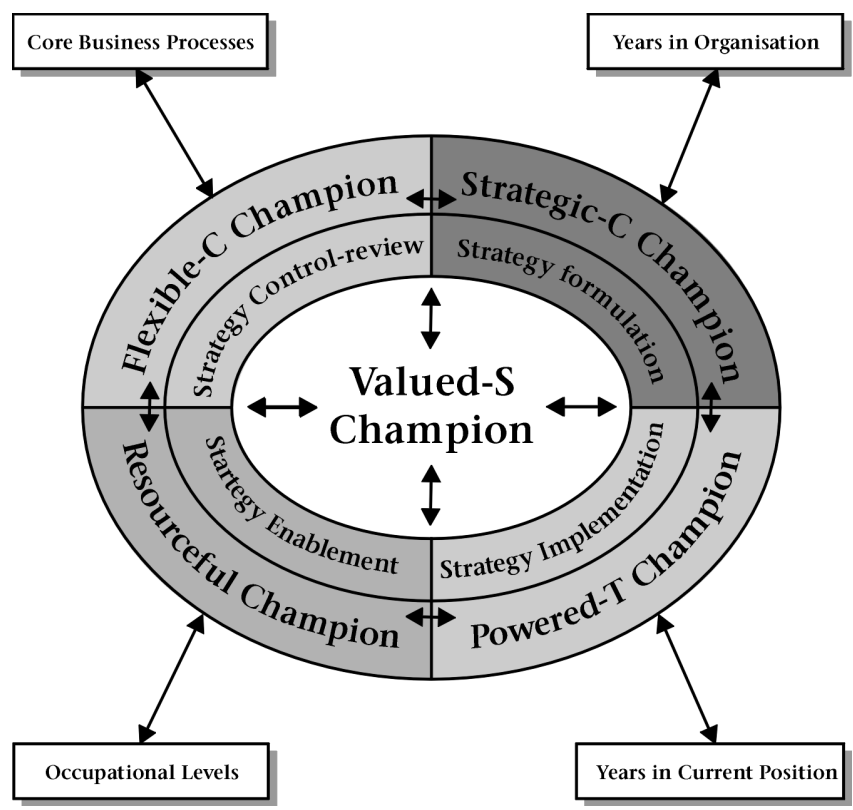

Figure 2: IL-C sub-roles relative to the four strategic management processes

According to the empirical findings reported in the results section IL-C is a single construct leadership relative to strategic management process, and must be seen as undifferentiated whole. When the importance of the IL-C was tested across the four strategic management processes it was found to relate best to all processes. However, IL-C was of greater importance in the strategy implementation and enablement while of lesser importance in strategy formulation and control-review.

It was also established that the five IL-C sub-roles relate best to specific strategic management processes. The Strategic-C Champion related best to formulation; Resourceful Champion and Powered-T Champion related best to implementation and enablement; Flexible-C Champion to control-review; and Valued-S Champion related best to enablement and control-review.

Contextual variables did not have any influence on the proposed links and importance of the IL-C across the strategic management processes. These findings suggest that leadership can emphasise the importance of five IL-C sub-roles regardless of differences in contextual variables. A common approach thus can be adopted in terms of leadership role relative to strategic management.

The results of this study have potentially important practical and theoretical implications. The first implication of the above findings is that individual/team goals could become misaligned with those of the organisation if people are going to act during strategy implementation without a clear understanding of organisational direction and strategy. A near fatal outcome could be a lacking sense of achievement, and the failure to utilise the opportunity to improve from lessons learnt during performance review sessions.

The leadership styles of past as well as of present leaders may have entrenched ways of doing things in an organisation. The second implication of the findings points to an indication of an action-oriented culture as opposed to a thinking-oriented one in the organisation. Leadership thus is regarded as being more important when it comes to implementing and achieving results than when envisioning is concerned. The organisation therefore deploys most of its resources (including people) at all levels with the aim to deliver set strategies.

The third implication of the findings concerns the organisational life cycle. The organisation may already have passed through the phase of formulation (i.e., they know what goals to achieve and how to achieve them) and there may already have been an improvement after the initial cycle of performance assessment. If they are now in the implementation phase, what they need to do is to enable people to perform successfully.

Theoretically, the study contributes to the body of knowledge with respect to the importance of leadership roles relative to strategic management processes. To date, most researchers have focused less on leadership roles relative to the strategic management process.

\section{Strengths and limitations of the study}

The strengths of this study are as follows:

- Firstly, the IL-C model with its suggested links and levels of importance was formulated and empirically shown to hold up. Secondly, the establishment of IL-C sub-roles linked to specific strategic management processes provides an opportunity to distinguish sub-roles competencies and behaviour that can provide valuable input into leadership development.

The limitations of the study are as follows:

- Firstly, the findings of this study are limited by the unique nature of the sample organisation, which limits generalisation to other organisations and industries. 
- Secondly, the IL-C questionnaire has 35 items rated across the four strategic management columns by the same respondents. This could have caused an error of acquiescence that could have affected some items negatively.

\section{CONCLUSSION}

Leadership determines excellent corporate performance. Leadership success in the implementation of the strategy is manifested in a conducive organisational climate; a reward strategy that is linked to strategic objectives; flexible structures that support business demands; and an effective organisational culture that influence behaviour in the right direction. The ultimate desired end results manifest itself in aligned individual and organisational performance.

The study demonstrated that an integrated, holistic and systematic approach to leadership, with its constituent subroles relative to strategic management, is needed. Determining and/or distinguishing the competencies and behaviour of each sub-role within defined performance contracts could be of value to business. The aim is to enable leaders to know their areas of development relative to expected outputs.

In view of the study's findings, it is concluded that the IL-C model with its suggested links and levels of importance do hold up. Through the organisational development process the proposed IL-C Framework can be utilised to operationalise leadership roles relative to the strategic management processes in organisations. The overall importance and value of the study lie in underlining the increasing importance of leadership in a growing uncertain environment in which appropriate strategising supported by relevant leadership roles is critical.

\section{REFERENCE}

Chapman, J.A. (2002). A framework for transformational change in organisations. Leadership and Organization Development Journal, 1 (23), 16-25.

Conradie, W. (February 2001). Management, leadership, entrepreneurship: all the same? Management Today, 1 (17), 35-38.

David, F.R. (1999). Strategic Management: concepts. Upper Saddle River: Prentice Hall.

Graetz, F. (2000). Strategic change leadership. Management Decision. 8 (38), 550-562.

Koopman, J.C. (Fall 1999). Effective alignment: strategy cannot succeed without it. Canadian Manager, 3 (24), 14-5.

Leichtling, B. (June 2000). Leaders take responsibility for success. Denver Business Journal, 43 (51), 28-29.

Margerison, C. (2001). Team competencies. Team Performance Management: An International Journal, 8 (7), 117-122.

Mattis, M.C. (2001). Advancing women in business organisations. Journal of Management Development, 4 (20), 371-388.

Melilli, D. (June 2000). A shift in leadership. Crain's Cleveland Business, 27 (21), 7-8.

Picken, J. \& Dess, G.G. (Summer 1997). Out of strategic control. Organisational Dynamics, 1 (26), 35-48.

Robbins, S.P. (1998). Organizational Behaviour: Concepts, controversies \& applications. Englewood Cliff: Prentice Hall.

Rodwell, J. J., Kienzle, R. \& Shadur, M. A. (1998). The relationships among work-related perceptions, employee's attitudes, and employee performance: the integral role of communication. Human Resource Management, 37 (3-4), 277-293, Fall/Winter.

Schultz, L.E. (2000). Qualities of an exceptional leader. Human Systems Management, 2 (19), 93-103.

Smit, P.J. (1999). Strategic Planning Readings. Cape Town: Kenwyn.

Thompson, J.L. \& Strickland, A.J. (1999). Strategic management. Richard D Irwin. New York.

Van Zwieten, J. (June 1999). How to waste your investment in strategy. Training and Development, 6 (53), 48-53.

Weizmann, J. (January 1999). Linking rewards to business goals can pay off. Washington Business Journal, 37 (17), 37-45. 